\title{
Investigation of Speech Acts of the Provisional Agreement of Intent
}

\author{
Muhammad S. Shehadeh ${ }^{1} \&$ Mahmud H. Wardat ${ }^{2}$ \\ ${ }^{1}$ University of Hail, Saudi Arabia \\ ${ }^{2}$ Yarmouk University, Irbid, Jordan \\ Correspondence: Muhammad S. Shehadeh, University of Hail, Saudi Arabia. E-mail: \\ muhammad.ababneh@yahoo.com
}

Received: February 20, 2017 Accepted: March 18, 2017 Online Published: July 15, 2017

doi:10.5539/ijel.v7n4p8 URL: http://doi.org/10.5539/ijel.v7n4p8

\begin{abstract}
This study investigated the provisional agreement of intent or the so called (Atwa) as a means of reconciling tribal disputes and conflicts from a socio-pragmatic perspective. The data consisted of forty provisional agreement documents on car accidents occasions, three video-recorded interactions and information collected via personal contacts with twelve interlocutors. The video-recorded materials and documents were categorized in accordance with politeness speech acts. The interviews concentrated on the personal details of the interlocutors in order to specify the main characteristics of those people and why they were chosen for this mission. This research finds out that frequently exchanged politeness strategies in the provisional agreement interaction include request, apology, honorifics, offering, compliment and thanking. Additionally, the researchers also found out that age, level of education, social rank, religion and socio-economic status were the sociolinguistic variables behind choosing the interlocutor.
\end{abstract}

Keywords: provisional agreement, interlocutor, speech acts, socio-economic status

\section{Introduction}

It is apparant that the starting point of investigating the language -society relationship lies within these two broader terms. Warldhaugh $(1986$, p. 1) states that "When two or more people communicate with each other in speech, we can call that system of communication that they employ a code. In most cases that code will be something we may also want to call a language."

Warldhaugh (1986, p. 1) defines society as "any group of people who are drawn together for a certain purpose or purposes". He also defines language as "what the members of particular society speak". To connect these two definitions with each other, the result is sociolinguistics. Milroy (1980, p. 1) defines sociolinguistics as "language in the community; that is, the observation and analysis of language in its social context as it is used in everyday situations".

Adopting this given definition, it can be concluded that sociolinguistics is the study of language in its social contexts and based on data collected from live speakers in everyday life. Stockwell $(2007$, p. 2) specifies that "it would be difficult to see any linguistic situation that did not come with the concern of sociolinguistics". From another sociolinguistics point of view, sociolinguistic variation is the investigation of the way the language varies and changes in communication and focuses mainly on the interaction of social variables such as gender, age, social class, region, etc. (Eckert, 1997, p. 151)

Leech $(1983$, p. 1) argues that one cannot figure out the language nature if he does not understand how language itself utilized in communication. That is to say, we cannot recognize the nature of the language without a pragmatic grasp. Cummings (2005, p. 2) also claims that pragmatics has a feature to impinge on other linguistic disciplines. Basically, Leech (1983, p. 6) defines general pragmatics as "the study of meaning in relation to speech situations". Cruse (2000, p. 16) pursues a standard definition of pragmatics:

Pragmatics can be taken to be concerned with aspects of information conveyed through language which are not encoded by generally accepted convention in the linguistic forms used, but which none the less arise naturally out of and depend on the meanings conventionally encoded in the linguistic forms used, taken in conjunction with the context in which the forms are used.

Apparently, Cruse intends to make his definition as broad as possible, so it is couched in that manner in order to 
make it inclusive of all utterances. However, this definition is exclusive of non-linguistic utterances like hallucination. In addition, it also includes semantic meaning in which one must recognize what a certain word means in a given language. No pragmatic definition, indeed, would be complete in the absence of context. Recognizing pragmatic meaning entails the physical setting within which a certain utterance is produced.

Leech (1983, p. 6) mentions that meaning in pragmatics is defined relative to a speaker or user of the language while meaning in other related fields like semantics is recognized as a feature of expressions in a certain language in the abstract form. Broadly, pragmatics is concerned with the meaning in use rather than the meaning in the abstract sense. Leech (1983, p. 10) maintains two types of general pragmatics: pragmalinguistics and socio-pragmatics. He points out that socio-pragmatics is the functional study of the socio-logical interference of pragmatics and it is culture-specific, whereas pragma-linguisics is language-specific. This means that one has to recognize that pragmatics analyses have to be associated with certain social situations and must consider the mechanism in which politeness is diversely clarified in different societies like Arab, American, and Chinese ones, among others.

Brown \& Levinson (1987) argue that searching for agreement through conversation is a manifestation of politeness strategies in language. This means that the listener and hearer both in seeking agreement maintain politeness strategies through using politeness devices such as "yes, of course yes, I do agree, that is so". These devices lead to the formalization of agreement and disregard other disagreement opinions, if any, and look for agreement by achieving politeness strategies.

Holmes (1995, p. 32) asserts that agreeing with someone is considered a positive politeness function, whereas disagreement poses a problem in politeness. Through seeking provisional agreement, there may appear different politeness realizations like thanking, offering, request, and apology that can be studied pragmatically and sociolinguistically. Pragmatics and sociolinguistics share many areas of common interest Levinson (1983, p. 374) states that sociolinguistics contributes much to the study of speech acts and their use. Nevertheless, pragmatics also attributes to sociolinguistics. To grasp the social significance of patterns of language usage, it is necessary to comprehend the underlying structural properties and processes that constrain a verbal interaction. Thus, the researchers discuss some sharing boundaries like speech acts, their use, and social features of the interlocutor. This study addresses the provisional agreements and the speech acts used to achieve them. Furthermore, investigating politeness strategies entails taking into consideration the sociolinguistic variables that affect the interlocutor of the provisional agreement.

\section{Provisional Agreement of Intent: Definition}

In this part of the study, the researchers shed light on the meaning of the term agreement in general and defines provisional agreement of intent in particular in terms of its proceedings, goals and types.

\subsection{Defining Agreement}

The word agreement refers to a social action in which two different parties are involved. According to The Word Book Encyclopedia Dictionary (1964, p. 42) agreement means "an understanding reached by two or more persons, groups of persons, nations among themselves." Webster's Ninth New Collegiate Dictionary (1990: 65) describes agreement as the "harmony of opinion, action, or character." Thus, agreement is a state of sharing or exchanging the same opinions, views, ideas, thoughts and feelings between two or more persons like interlocutors and truce guarantors in provisional agreement.

\subsection{Defining Provisional Agreement of Intent}

The provisional agreement of intent for tribal reconciliation or the so called (atwah) is a traditional practice that occurs in social contexts during the course of everyday life. This line of agreement as such starts when a problem arises between two or more different tribes. The perpetrator's family resorts to a tribal chief who belongs to a different tribe and asks him to intermediate between the conflicting parties to settle the conflict.

\subsection{Importance of this Agreement}

Short-term agreement is of importance in tribal Arab jurisdiction for many considerations. Indeed, if the family of the victim agrees on giving (ațah), it usually implies that they are giving their preliminary consent to the eventual peacemaking. It aims at preventing the victim's family from taking revenge on the perpetrator or his family or patrilineal relatives, resolving problem, tightening the spot of dispute and making peace. Al-Tal (1997, p. 255) addresses into the gravity of the provisional agreement. He mentions that (ațah) aims at reducing disputes, hostility and conflict, preventing the victim's family from taking revenge on the offender, and making peace in the society. Besides, he states that (atwah) gives the perpetrator's family a chance to change their place of living especially in severe crimes. Nevertheless, changing the place of living does not imply that the offender will escape 
with his crime, but it bans the vistim's family from any illegal actions against the perpetrator or his family untill enforcing the civil or tribal law. Broadly, the provisional agreement of intent is a mechanism to support the official law in Jordan. (Note 1.)

\section{Methodology}

In the previous chapter, we review previous studies that investigate agreement, its type, disagreement and the strategies used by the interlocutor to reconcile the dissenting parties. In this chapter, the researchers discuss the research methods adopted throughout the present study including population, sample of the study, data collection, data analysis and limitations of the study.

\subsection{Population}

The population of this study consists of all Jordanian tribes in the North region of Jordan. In fact, the researchers chose this region because it has a high degree of unified habits, customs and traditions. This reason provides us with the chance to gain the data required for the purpose of the study.

\subsection{Sample of the Study}

The researchers interviewed twelve experienced interlocutors from the cities of Irbid, Jarash, Ajloun and Mafraq. Because the majority of the population (nearly one million) is found in Irbid, six interlocutors were interviewed from Irbid and two interlocutors were identified from the other mentioned cities. After that, six interlocutors were randomly chosen for the purpose of the study. Three interactions were taken from each of the above mentioned cities. See the appendices.

\subsection{Data Collection}

In order to collect reliable data for this study, the researchers attended three real-life provisional agreement interactions. The conversations themselves are spontaneous and unstructured so that the findings are more reliable than the data collected through other methods like experimental ones. However, the requirement that the participants, "the conflicting parties", give consent to have their conversations video-recorded unavoidably affects the spontaneity of the event. Besides this, the researchers interviewed twelve experienced interlocutors from Irbid, Ajloun, Jarash and Mafraq in North Jordan and asked them about their age, rank, level of education and socio-economic status. Even though the interviews were unstructured, the researchers asked the interlocutors specific questions. These questions were:

1) How old are you?

2) What is your educational level?

3) What is your present-or fromer job?

4) Do you think that the financial status of the interlocutor has a great importance in the reconciliation process?

5) Do you refer to religious texts in the provisional agreement?

Furthermore, forty written provisional agreement documents were collected from previously mentioned cities.

\subsection{Data Analysis}

The researchers analyzed the written and spoken data from a pragmatic perspective in terms of request, apology, honorifics, offering, compliment and thanking. Afterwards, the researchers transliterated the written and spoken (recorded) data utilizing Arabic phonetic symbols, taking into consideration the sociocultural and socioeconomic dimensions of interlocutors like age, level of education, rank and financial status. More obviously, these dimensions were divided into subcategories according to their effect on the process of choosing the interlocutor.

\subsection{Limitations of the Study}

This study has a number of limitations that should be noted. Firstly, the researchers limited themselves to probing the sociolinguistic and pragmatic aspects of speeches delivered in the provisional agreement of intent. The researchers, however, left out other related linguistic fields such as semantic and syntactic analyses. Secondly, the researchers examined the interactions that occur just in the car- accident provisional agreement and left out the interactions of that agreement in other kinds of crimes like manslaughter, crimes of passion and armed attack. Thirdly, the population of this study is from the northern region of Jordan, thus reducing the generalizability of the results to other regional varieties in Jordan. Finally, this study is concerned with politeness strategies.

\section{Analysis}

The analysis of this study consists of two parts. In this first part, the main speech acts used in provisional agreement of intent of car-accidents were discussed. In the second part of the analysis, focus is placed on the 
sociolinguistic variables of the Interlocutor.

\subsection{Speech acts of Provisional Agreement of Intent}

\subsubsection{Request}

Since request is an essential part of language in general and provisional agreement in specific, it is noteworthy to define the concept "request" by linguists. Searle (1979, p. 3) defines request as "an attempt to get the hearer to do something". Also, Stenstorm (1994, p. 40) considers it as one of the primary acts in which the speaker asks someone to do something.

The speech events of provisional agreement are mainly held to make a request. In fact, the act of request is performed by two parties, namely, the gentry and the victim's family. The gentry usually requests to conduct a provisional agreement and to set free the driver, whereas the victim's family usually requests payment for hospital or treatment costs and compensate for the injury which occurred. (Note 2)

The interlocutor says:

الجاهة الكريمة جاءت الى ديو انكم العامر في اثر الحادث المؤسف الذي أصيب ابنكم فيه ونسأل الله الثفاء العاجل

adz--dza:hah ?al-kari:mah dza:?at ?ila: di:wa:nikom ?al-乌a:mir fi: ?aөar ?al-ha:die ?al-mo?sif

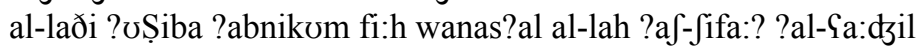

The esteemed gentry paid a visit to your flourishing guesthouse in the aftermath of the woe accident which resulted in the injury of your son, to whom we wish immediate recovery.

One may affirm that the act of request is not present in the above mentioned excerpt. However, the interlocutor does not implicitly request the victim's family to set free the offender; rather, he talks about reconciliation before this utterance, and then he moves to talk about the terrible accident. When the interlocutor mentions that gentry come owing to this car accident, he implicitly requests that the victim's family sets free the offender.

The victim's grandfather replies:

بدنا شفاء الولد احنا بدنا شك تأمين مع أي ناس في الجاهة

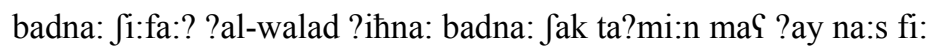

adz-dza:hah

We want the boy to get recovered; we also want a guarantee cheque kept with any member of the gentry.

From the above mentioned examples, it is clear that the act of request performed by the gentry is implicit, whereas its counterpart, that of the victim's family, is explicit. In reality, this behavior can be attributed to the role of each party in the process of reconciliation which is mainly governed by tribal customs and traditions. Being a representative of the offender's party, the gentry does not have the right to perform an explicit request, so the interlocutor mentions that gentry comes to the victim's guesthouse because of the car accident. His grandson injured in the car accident, the victim's grandfather performs an explicit request by asking for the hospital or treatment costs. Apparently, the victim's request is somewhat explicit because their rights are already guaranteed by both the tribal jurisdiction and civil law; i.e., if the request of the victim's family is not met by the tribal jurisdiction, the victim's family, of course, will appeal to the civil court.

The formulas of request are different in terms of politeness. The request of the delegation is more polite than that of the victim's family. This result can be illustrated by the above examples; the victim's grandfather uses twice the verb "want", whereas the delegation seems to be polite by avoiding the verb "request" to release the offender.

However, the delegation seems to be very direct in requesting the victim's family to conduct the provisional agreement but indirect in requesting that they release the offender.

The interlocutor says:

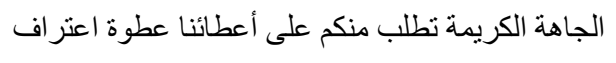

adz-dzaha ?al-kari:mah tațlob minkom Sala: ?iSṭa:?ina: Yațwat ?iStiraf

The whole gentry is ready to bear the full brunt of the unintentional fault.

Directly asking to release the offender is considered impolite at this stage of reconciliation. Even though the victim's family usually agrees to set free the driver when conducting the provisional agreement, the interlocutor's goal is to prevent any revenge or potential offensive act of the victim's family; therefore, he does not hesitate to be very direct in requesting the victim's family to agree to conduct the provisional agreement. 


\subsubsection{Apology}

Apology is a speech act intended to give support for the addressee who is offended by the speaker (Olashtain, 1989, p. 156). By virtue of the fact that the interlocutor represents the offending party, he expresses his sorrow for the offensive behavior by admitting the fault and offering compensation for what has happened.

Lackoff (2001, p. 201) specifies that apology differs slightly from most speech acts concerning the psychological burdens that it places on its apologizer and its impact on the apologizee. Broadly, the forms of apologies range from explicit and direct to ambiguous and indirect. Consider the following example:

(Note 3)

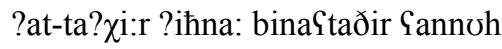

We all apologize for being late.

The speaker apologizes for being late to seek the provisional agreement of intent in the intended timeframe. It seems clear that the interlocutor in this example directly expresses apology. Based on the above example and the researchers' observations, interlocutors are likely to be explicit in performing the act of apology. The state of being direct and explicit enables the interlocutors to be more influential since this act has a psychological impact on the victim's family in specific and on their relatives in general. Besides, this act admits the perpetrator's responsibility for the car accident which, in turn, helps the interlocutor achieve the provisional agreement of intent.

The directness in apology is also represented in the following example:

الاعتذار منا شديد.

?al-?ątiða:r minna: Jadi:d

We strongly apologize

When directly performing the speech act of apology, the interlocutor is most likely to be polite in addressing the audience. This fact could be recognized using two mechanisms: the word "strongly" (fadi:d) and the forms of address (minna:). Actually, he uses "strongly" to express his deep apology for the car accident which, in turn, leads him to be polite. The interlocutor uses the first plural pronoun "we" (na:) to convey that the delegation are all offering an apology for the unpleasant behavior, the car accident. The appropriate expression enables the interlocutor to be polite in addressing the victim's family.

Admitting fault is a strategy interlocutors employ to acknowledge openly and truly that the driver has has done wrong to the victim. The apology strategy of urgent reasons provides apologizees with justification in clarifying that the occurrence of the car accident has been caused by uncontrollable circumstances. This strategy is clearly represented below:

الجماعة اصدقاء مع بعض ولكن القدر ساوى الحادث .

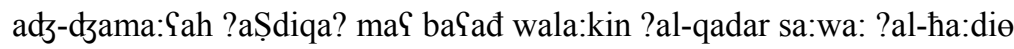

The two parties are friends but it is their destiny.

Actually, the interlocutor expresses sorrow or remorse for what the driver had done. He attributes the occurrence of the accident to destiny. This urgent reason of the car accident is regarded as a strategy the interlocutor utilized to rationalize or smooth over the occurrence of the incident. So it is plausible to state that the interlocutor seems to be very polite in addressing the audience. Such a strategy enables the interlocutor to convince the victim's family to give the provisional agreement of intent. More obviously, offering the urgent reasons of apology is considered a very influential mechanism to persuade the victim's family to give the provisional agreement since this strategy is accomplished with sorrow and remorse which, in turn, lead to the realization of politeness.

In a summary, interlocutors are likely to be polite in showing the act of apology since it is considered as a crucial strategy to persuade the victim's family to give the provisional agreement of intent. Directly performing the act of apology makes the interlocutor very polite in expressing this persuasive strategy.

\subsubsection{Honorifics}

The speech event of provisional agreement of intent is a large amount of honorific formulaic expressions. Brown and Levinson (1978, p. 22) specify that "honorifics provide obvious and important evidence for the relation between language structure, politeness and social forces in general". That is, honorifics are generally a mechanism to show deference by manipulating structures of language. Braun (1988, p. 45) mentions that "forms of address are a good example of politeness expressions for the system of address appearing to be elaborated in all languages." Manipulating the structures of language can be illustrated by the forms of address since address variants are likely 
to be universal. The most frequent honorific expression related to the forms of address is the following:

الجاهة الكريمة.

adzdza:hah ?al-kari:mah

The esteemed

The interlocutor initiates his talk by addressing the gentry. The honorific expression (?al-kari:mah) "esteemed" is intended to direct the audience's attention in general and the gentry in specific towards what he is going to say. Actually, the act of performing the mediation process is considered prestigious and praised by different socioeconomic levels in North Jordan. The person who performs this act receives honorifics and deference by people in North Jordan. This fact can be illustrated by one of the interlocutor's speech:

كل الثكر للجاهة الكريمة التي قدمتني لأتكلم بأسمه و انا لست بأعلمهم و لا أفصحم لسان.

kol af-fokor laldza:hah ?alkari:mah ?allati: qaddamatni li?atakallam bi?asmihim wa?ana lasto bi?alamihim wala ?afȘahihim lisa:n

I am very thankful to the esteemed gentry for presenting me as their spokesman though I am not the most laureate one.

The interlocutor thanks the delegation for choosing him to speak for them. In the above example, the interlocutor seems to be very polite in addressing the delegation since he is very likely to be humble. He does not consider himself as the most knowledgeable and articulate person among the delegation.

Another example of honorifics with the forms of address is the following:

بناء على طلب الباشا.

bina:? Sala: țalab ?al-ba:fa:

Upon the major-general's request

Military honorifics are maintained by Jordanians in the Northern region. This fact can be recognized by the speech event delivered by Jordanians in provisional agreements of intent. Boss (ba:fa:) is a very high military rank in the Jordanian Armed Forces. By addressing the interlocutor (ba:fa:), the speaker, one of the afflicted party, intends to show honorifics which, in turn, lead to the manifestation of politeness in his speech. The speaker shows the interlocutor's deference and intimacy by addressing him (ba: $\left.\int a:\right)$.

Situational honorifics are also highly maintained in the provisional agreement. Actually, situational honorifics are different from the honorifics with the forms of address in one main perspective. Situational honorifics are expressed in isolation as responses and do not entail any form of address. Examples of situational honorifics exchanged in the provisional agreement are presented below:

You are most welcome

May Allah reward you.

Bless you.

You are the blessing.

May Allah aid you.

$$
\begin{aligned}
& \text { ?allah yahayi:k } \\
& \text { dzaza:k ?allah } \text { ayr } \\
& \text { fi:k ?al-barakah } \\
& \text { ?ant ?al-barakah } \\
& \text { ?allah yaku:n fi: Su:nak }
\end{aligned}
$$

$$
\begin{aligned}
& \text { الله يحييك } \\
& \text { جز اك الله خير } \\
& \text { فيك البركة } \\
& \text { أنت البركة } \\
& \text { الله يكون في عونك }
\end{aligned}
$$

These examples are highly exchanged in provisional agreements of intent. The functional recurrence of these formulas shows intimacy and camaraderie between the delegation and receiving party. These utterances share certain features of linguistic etiquette which are politeness, positive face and appropriateness to the context. Actually, exchanging such situational honorifics indicates that the afflicted party agrees to conduct the provisional agreement. (Note 4)

\subsubsection{Offering}

This strategy is used by the interlocutor to offer the addressee something that might improve an unpleasant situation, or rather what could render a bad situation better. Thus, the interlocutor almost always exploits this strategy to compensate the victim's family for being exposed to an offensive behavior. (Note 5)

It seems logical that the interlocutors in the provisional agreement interaction are likely to be very direct to offer compensation for the injury or even death caused by the car accidents. This finding is illustrated below:

$$
\text { الجاهة كلها تحت أمرك }
$$

adz-dza:hah kolha: tahit ?amrak 
The gentry all are under your command.

ا احنا مستعدين للي بدكم اياه.

?iћna: mustaGaddi:n lalli: bidkom ?iyya:h

The gentry are all set to do whatever you want

The interlocutor is very direct to offer compensation. The state of being direct is illustrated by indicating that not only the interlocutor but also the whole delegation are willing to carry out the requests of the victim's family. Speaking for the delegation leads to the realization of politeness which, in turn, positively affects the decision of the victim's family. The more the interlocutor is direct and polite in offering compensation, the more he is effective in the decision of the victim's family.

\subsubsection{Compliment}

Positive politeness can be expressed by any mechanisms, one of which is paying a compliment. "A compliment is a speech act which explicitly or implicitly attributes credit or someone other than the speaker, usually the person addressed, for some good characteristic" (Holmes, 1986, p. 485). It has been noted that the interlocutor in the provisional agreement mentions what the afflicted party likes to hear.

The interlocutor says:

$$
\text { لطيب طيبكم وأنتم أهله. }
$$

?aț-ți:b ți:bakum wa?antum ?ahloh

You are the people of good deeds.

$$
\text { أنتم من الناس الذين نعتز بهر. }
$$

?antom min ?anna:s ?allaði:n naStaz bihim

You are of the people whom we are proud of .

It is quite evident that the above mentioned formulas are exchanged by the interlocutor in order to express compliments. Wierzbicka (1987, p. 201) states that compliments are expressed to make addressees feel good. However, the above mentioned formulas of compliments seem to increase or consolidate the solidarity between the interlocutor and the victim's family. The primary function of the compliment is affective, rather than referential or informative. That is, the speaker does not attend to add new information about the addressees; rather, it is a mechanism to persuade the victim's family to conduct the provisional agreement or even to reach reconciliation.

In the above examples, the interlocutor explicitly expresses compliments. Explicit compliments provide the interlocutor with a persuasive mechanism to convince the afflicted party to give the provisional agreement.

\subsubsection{Thanking}

This politeness strategy is performed at the end of negotiation as a realization of conducting the provisional agreement of intent. Although this strategy is not performed when the victim's family does not agree to conduct the provisional agreement, it is of importance. The gravity of this strategy comes from the fact that the interaction aims at paving the road to peacemaking. More obviously, even though thanking is not a persuasive strategy as making an apology and offering to conduct the provisional agreement, this strategy is meant to reach peacemaking. Thanking enables the interlocutor to be polite in addressing the victim's family. Politeness in turn is a mechanism to cause the victim's family to give the provisional agreement and also to reach peacemaking. Consider the following:

$$
\text { ان من لا يشكر الناس لا يشكر الله }
$$

?inna man la: yajkor an-na:s la: yafkor alla:h

He who does not thank people does not thank Allah.

The interlocutor directly thanks the victim's family for their approval to give the provisional agreement. The directness of thanking is recognized by repeating the verb "thank" twice in the above example.

The directness of thanking is also present in the following example:

شاكرين لكم كل ذرة خير بذلتمو ها

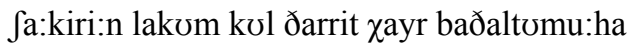

"We thank you for all your efforts"

The importance of this speech act is also realized in documenting this strategy in the provisional agreement decree. 
To sum up, this strategy is considered a manifestation of the interlocutor's politeness in addressing the receiving party, and it aims at setting scene to reach peacemaking.

Having explored the speech acts used in the provisional agreement of intent, the next step is to analyse the sociolinguistic variables of the interlocutor.

\subsection{Sociolinguistic Variables of the Interlocutor}

The interlocutor or the so-called "waki:1 ?ad-dafa:" has an integral role in the process of reconciliation. Many scholars like Al-Hashash (1993, p. 13), Abo-Khawsah (1993, p. 98), and Al-Tal (1997, p. 109) study the characteristics of the interlocutor from an anthropological point of view. Al- Hashash (1993, p. 13) mentions some of these characteristics:

- The interlocutor has to be male; females are not allowed to intermediate between the dissenting parties.

- He has to be accepted by the afflicted party.

- He has to be rich enough to pay if the offender's party cannot pay all of the rights of the victim's family.

- He must not belong to the conflicting parties.

This study is an attempt to investigate the sociolinguistic variables and socio-economic status of the interlocutor. The sociolinguistic variables affecting the process of choosing the interlocutor are age, level of education, social rank, religion, and socio-economic status. These variables play a vital role in choosing the interlocutor. Otherwise, if the interlocutor lacks some or all of these variables, mediation in the reconciliation process may be rejected by the victim's family. In this case, the offender's family must, in turn, look for another interlocutor having these characteristics. The researchers discuss some sociolinguistic variables leading to having a well- accepted interlocutor, on the one hand, and the implications of these variables on politeness, on the other. In this action, the researchers answer the present -study question: what are the sociolinguistic variables in the process of choosing the interlocutor?

\subsubsection{Age}

Age plays an integral part in the process of choosing the interlocutor. The researchers meet twelve well-experienced interlocutors in the North region of Jordan. They finds out that the youngest one of them is past fifty years old. This result shows that the role of the age in the reconciliation process is highly significant. The data confirms that elderly men are greatly regarded and respected by other people.

Some of the audience says

$$
\text { فيك البركة با حجي }
$$

fi:k ?al-barakah ya: hadłdzi:

You are a blessed man, Haji.

The word Haji in Jordan is considered polysemous. In fact, it has two meanings: one who performs pilgrimage, and the one who is an elderly man. (Haji) is mainly associated with elderly men in Jordan because most of Jordanians perform pilgrimage between fifty and sixty years old. In this context, this utterance does not necessarily mean that the addressee is a pilgrim; rather, it is said to show that the addressee is old. One piece of evidence that (Haji) means an elderly man is that the speaker of this utterance does not most likely know that the addressee has actually performed pilgrimage; therefore, this utterance is associated with respect, honorifics and deference. Moreover, this utterance shows a high mechanism of politeness in addressing the elderly. This result can account for the fact that age plays a prominent and determining factor in choosing the interlocutor.

Some of the audience also says:

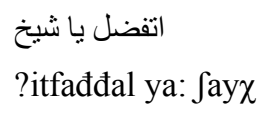

The floor is yours, Sheikh.

Addressing elderly people in the provisional agreement negotiation shows deference and respect. This fact is illustrated in the utterance "sheikh". According to Arab traditions, every tribe has one main sheikh who is considered as the chief of that tribe. The sheikh is almost always an elder member of the tribe. Addressing one as a sheikh is considered a polite way owing to the relation between the state of being a sheikh and the state of being an elderly man. That is, if we describe one as a sheikh in Jordan, it usually implies the addressee is an elderly man. Conventionally, being an elder man among the gentry is most likely to be important as a characteristic of the interlocutor. 
These two expressions entail a higher degree of politeness maintained by the attendants and directed towards the elder man on the speech event of the provisional agreement. Attendants imply deference and regard to the elderly interlocutor. Furthermore, utilizing appropriate honorifics like (Haji) to address the elderly man is a sign of respect.

Generally speaking, these examples reveal that Jordanians usually prefer elderly men as interlocutors to rather young ones in the reconciliation process. This finding seems to be attributed to the fact that it would be difficult to disappoint elderly men in request to conduct the provisional agreement; therefore, the perpetrator's family appeal to elderly men to mediate between them and the conflicted party. The pertinent question is: Why does age play a significant role in the provisional agreement of intent? The answer lies in two reasons: religion and traditions. With regard to religion, Islamic teachings urge, if not order, Muslims to respect elderly men. This is illustrated in Prophet Muhammad's saying:

ليس منا من لم يرحم صغيرناويوقر كبيرنا

laysa minna man lam yarћam Șagii:rana: waju:waqqir kabi:rana:

He who neither mercies our minors, nor highly appreciates our elders is not one of us.

This prophet Muhammad's saying is found in Jama' Al-Tarmithi, page (324).

In Jordanian traditions, the first man who comes into the guesthouse of the victim is the oldest man among the delegation. This etiquette shows respect, deference and honorifics which, in turn, lead to the realization of politeness norms. Politeness directed towards the interlocutor seems significant to help conduct the provisional agreement.

\subsubsection{Level of Education}

The interlocutor's level of education plays a crucial role in the process of selecting the speaker in the provisional agreement of intent. Among the six randomly-chosen interlocutors, the researchers found that two of them had a secondary certificate, whereas the rest had B.A.'s. This data shows that one third of the present-study sample is well-educated. Therefore, the level of education plays a crucial role in choosing the interlocutor. The level of education affects the ability of the interlocutor to speak formally which, in turn, leads him to be welcomed by the conflicting parties. Using Standard Arabic through the interaction of the provisional agreement of intent is appreciated and admired by all members of the Jordanian community. This fact is supported by the face-to-face interaction through the provisional agreements. This result comes from the fact that Standard Arabic in Jordan is the official language used by media, government and lecturers. The more eloquent and formal the interlocutor is, the more respect and deference he receives. The fact that the Standard Arabic user usually receives respect and deference is one piece of evidence for the importance of the level of education as one important characteristic of the interlocutor. Consider the following formal examples:

الحمد الله الذي جعل الحدد مفتاحا للكلام, و صلى على نبيه صلاة تقضى لها الحوائج و تنال بها الرغائب و تحسن بها الخو اتم

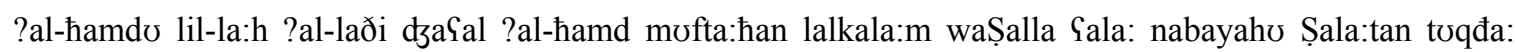

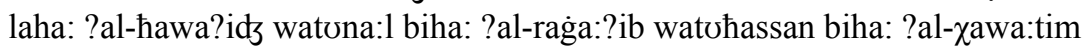

All thanks are due to Allah Who starts His holy book with praise and pays tributes to his prophet in a way that meets needs and ends.

This speech is considered acceptable by the audience. Their acceptance is represented by their positive facial expression. The researchers attribute the acceptance of the audience to the interlocutor's formality. The formality of the above speech comes from the fact that the interlocutor utilizes the preachers' speech in Islam. The proper idiomatic expressions: (?al-hamd lil-la:h) and (waȘalla Sala: nabayahð) are mainly delivered by the preachers especially at the beginning of their preaches. Resorting to preachers' speech in the provisional agreement is likely to be welcomed by the attendants since preachers are usually formal in their speech. That state of being formal by resorting to the preacher's speeches is likely to enable the interlocutor to be accepted by the audience.

Moreover, the level of education helps the interlocutor vary the persuasive strategies like thanking and compliments in convincing the victim's family to accept the provisional agreement of intent.

One interlocutor begins his speech with the following example:

$$
\begin{aligned}
& \text { السلام عليكم ورحمة الله وبركاته } \\
& \text { ?as-sala:mo Yalaykum warhmatu al-la:h wabaraka:tah } \\
& \text { Peace, mercy and blessings of Allah be upon you. }
\end{aligned}
$$

The interlocutor uses a greeting at the beginning of his speech. This formula is characterized by formality and 
courtesy. The politeness of this utterance comes from mentioning the full formula of greeting in Islam. Actually, in Jordan the above mentioned expression is preferred to other related greeting expressions:

السلام عليكم

as-sala:mu ?alaykum

Peace be upon you.

السلام عليكم ورحمة الله.

as-sala:mo ?alaykum waraћmat al-la:ah

Peace and mercy be upon you.

Using the full formula of greeting leads the interlocutor to be accepted by the audience, especially the afflicted party. This is because the full greeting expression is encouraged by Islam to be exchanged.

The same interlocutor proceeds with his speech by saying:

اتقدم بو افر الثكر وعظيم الامتنان

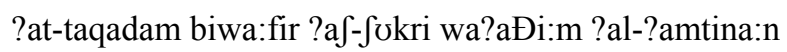

I present plentiful thanking and great gratitude.

He formally thanks the afflicted party for giving the provisional agreement of intent. Furthermore, he also formally exploits the speech act of compliment below:

أنتم أهل الخير

?antom ?ahil ?al- $\chi$ ayr

You are the people of good deeds.

Finally, the interlocutor utilizes the speech act of situational honorifics to express deference:

بارك الله فيكم

ba:rak al-la:h fi:kom

May Allah bless you all.

The speaker's level of education enables him to vary linguistic politeness speech acts like greeting, thanking, compliment and situational honorifics. This result indicates that the level of education helps the interlocutor use various politeness strategies which, in turn, lead him to be more prestigious and receive respect from attendants.

From the above discussion, the interlocutor's level of education in the provisional agreement of intent is very important. This competence enables the interlocutor to vary linguistic strategies such as thanking, compliments, and honorifics. Variety in politeness speech acts helps conduct the provisional agreement, pave the road to peacemaking and show prestige.

\subsubsection{Social Rank}

Interlocutors' social rank can be represented by their present-or former job. Interlocutors' rank seems an important criterion maintained by Jordanians in North region. The researchers discovered that most of the interlocutors he met have a very high rank in their community. Consider the following:

1) Retired major-brigadier and former deputy

2) Former deputy

3) Assistant governor

4) Retired major- general

5) Former employee

6) Businessman

The first four interlocutors have a very high rank, whereas the rest lack this variable. $66 \%$ of the randomly- chosen interviewed interlocutors have a high rank. This result indicates the significance of the social rank in choosing the interlocutor. Actually, social rank enables the interlocutor to be very influential on the dissenting parties, on one hand, and the Jordanian government which is represented by the police, on the other hand. Jordanians resort to a high-ranked interlocutor to solve their problems like ones caused by car accidents. For example, one of the randomly-chosen interviewed interlocutors in North Jordan usually gets one provisional agreement every month. 
That fact is attributed to his rank as being an assistant of a ruler in a city of North Jordan.

Jordanians show respect and deference to interlocutors with a high military rank. That is owing to their role in leading the army and protecting the state from any potential attack. Jordanians in Northern region believe that the person who has a high military rank is able to solve problems caused by car accidents.

From the randomly -chosen interlocutors, the researchers discovered that four of them have a very high rank in their community. Based on the researchers' observation, people in North Jordan respect interlocutors for their rank. This result indicates that the social rank is an important characteristic in the process of choosing the interlocutor because it leads people to be very polite in addressing them.

\subsubsection{Religion}

Undoubtedly, the characteristic of the interlocutor in Jordan is influenced by Islam. This influence can be shown by the interaction exchanged in the provisional agreement of intent. Speakers very often resort to some religious texts, either Quranic verses or Prophetic sayings. These texts are influential in helping the interlocutor obtain the victim's family's consent to give the provisional agreement of intent. The interlocutor first quotes Quranic verses relevant to the occasion of reconciliation, and then he may refer to Prophet Muhammad's sayings (PBUH).

The following illustrate some of these verses and sayings exchanged through the provisional agreement of intent:

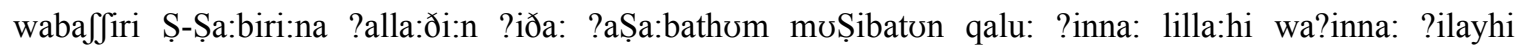
ra:dziৎu:na ?uwla:?ika Galayhim Șalawa:ton min rabbihim warhmaton wa?uwla:?ika hơmo l-lmohtadu:na (Al-Baqara, pp. 155-157)

Give glad tidings to patient ones who when afflicted with calamity say "truly! To Allah we belong and truly, to him we shall return". They are those on whom are the blessings from their Lord, and receive his mercy, and it is they who are the guided-ones. (Al-Hilali \& Khan, 1995, p. 64)

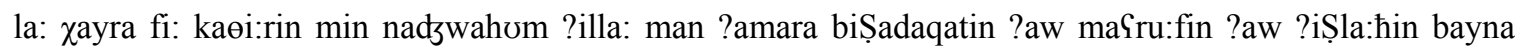
n-na:si waman yafYal ða:lika ?ibtig̀a:?a marđa:ti l-la:hi fasawfa no?tihi adzran ৎaĐi:ma (Al-Nisaa, p. 114)

There is no good in most of their secret talks save him who orders Sadaqa or Maruf, or reconciliation between mankind, and he who does this, seeking the good pleasure of Allah; we shall give him a great reward. (Al-Hilali and Khan, 1995, p. 161)

The use of these verses is very expressive and influential. In (1), the interlocutor reminds the victim's family of Allah's teachings that they should be patient on sad occasions, plights and catastrophes. The ability to quote relevant religious texts enables the interlocutor to be influential on the addressees in general and the victim's family in particular. The state of being influential by referring to religious texts is a prerequisite for the characteristic of the interlocutor. That finding is attributed to the fact that most Jordanians are influenced by Islam and show respect and deference to people who are committed by Islamic teachings. This result gives rise to preferring a committed interlocutor to an uncommitted one.

This result is also confirmed by the randomly- chosen interviewed interlocutors. When asking the interlocutors if they refer to religious texts, they all resposnded positively. In short, religion represents a vital factor in the process of choosing the interlocutor since it affects the intellect of the addressees. That is, religion is utilized to persuade the victim's family to conduct the provisional agreement of intent.

\subsubsection{The Socio-economic Factor}

When car accidents result in causalities or death, the victim's family may ask for an amount of money. The offender's family, in turn, has to compensate the victim's or his family for the crime caused by the car accident. The role of the interlocutor (waki:l ad-dafa:) is to first guarantee the offender's party in that they will pay all of the victim's family rights. Second, the interlocutor is willing to pay in case the offender's family cannot pay.

Based on the researchers' observation, the financial status of the interlocutor gives the victim's family a guarantee that their financial rights will be paid. In one of the provisional agreements of intent attended by the researchers, the interlocutor signed a cheque as a guarantee for the injured one's family.

Clearly, if the interlocutor were not able to guarantee the victim's family rights, his mediation would be rejected. When the interviewed interlocutors are asked if the economic status of the interlocutor is important as an interlocutor's characteristic, they do specify that the interlocutor should be rich enough to be able to guarantee the rights of the injured party. This result supports Al-Hashash (1993, p. 13) who states that the interlocutor has to be able to pay the rights of the afflicted party when the offender or his family does not pay all of the afflicted party's rights. 


\section{Conclusion}

Depending on 40 provisional documents, 3 video-recorded interactions, information from 12 interlocutors, the present study found that the most frequent speech acts of the face-to-face interaction are: request, apology, honorifics, thanking, compliment and offering. These speech acts are meant to show politeness by maintaining deference, veneration and intimacy. Request is the most important act of the provisional agreement speech event. Interlocutors are likely to be indirect in requiesting the release of the driver but indirect to ask to conduct the provisional agreement. Moreover, interlocutors are very likely to be more polite than the afflicted party in the act of request. They seem to be very direct in expressing apology. They use the urgent reason strategy for convincing the afflicted party to give the provisional agreement and showing politeness in addressing the audience. Honorifics are used to show politeness between the gentry and afflicted party. This speech event is regarded as an indication of the afflicted party's consent to the provisional agreement. Broadly, interlocutors are likely to be very direct in offering compensation. Compliments are directly intended to express solidarity and have an affective dimension rather than referential or informative one. However, the direct speech event of thanking is rather different from the mentioned strategies. Thanking is not a persuasive strategy of conducting a provisional agreement; rather, it is a persuasive strategy of peacemaking. This result accounts for writing down thanking in the provisional agreement.

The social variables affecting the characteristics of the interlocutor are age, religion, socio-economic status, and level of education. Age is the most prominent factor among them all because people in North Jordan respect and appreciate elderly men. The level of education enables the interlocutor to vary the politeness strategies in order to persuade the afflicted party to conduct the provisional agreement and in order to show prestige. Jordanians in Northern region respect interlocutors for their rank. Referring to Quranic verses or the Prophet Muhammad's sayings affects the intellect of the addressee which, in turn, helps conduct the provisional agreement. Finally, the economic status gives the afflicted party a guarantee that the offending party will pay all the afflicted party's rights. The more the interlocutor has these characteristics, the more he receives respect and politeness by Jordanians in North region.

\section{References}

Alhaisoni, E., Jarrah, M. A., \& Shehadeh, M. S. (2012). An investigation of evidentiality in the Arabic language. International Journal of Linguistics, 4(2), 260-273.

Al-Hilali, M., \& Khan, M. (1995). The Interpretation of the Meaning of the Nobel Qura'n in the English Language. Saudi Arabia: Dar-us-Salam Publications.

Al-Jarrah, R. S., Abu Dalu, A. M., \& Jarrah, M. (2015). A relevance-theoretical account of three Arabic pragmatic operators of concession in a political discourse. Lodz Papers in Pragmatics, 11(1), 51-76. https://doi.org/10.1515/lpp-2015-0004

Altakhaineh, A. R. M., Jarrah, M. A., \& Alsulayyi, M. N. (2014). Discourse meanings: An application of $\begin{array}{lllll}\text { intertextuality perspective. International Journal of Linguistics, } & 6(2), & 85 .\end{array}$ https://doi.org/10.5296/ijl.v6i2.5078

Braun, F. (1988). Terms of Address Problems of Patterns and Usage in Various Languages and Cultures. New York: Amesterdam. https://doi.org/10.1515/9783110848113

Brown, P., \& Levinson, S. (1978). Some Universals in Language Usage: Politeness Phenomena. In E. Goody (Ed.), Questions and Politeness (pp. 256-289). Cambridge: Cambridge University Press.

Cruse, D. A. (2000). Meaning in Language: An Introduction to Semantics and Pragmatics. Oxford: Oxford University Press.

Cummings, L. (2005). Pragmatics: A Multidisciplinary Perspective. Spain: Edinburgh University Press.

Eckert, P. (1997). Age as a Sociolinguistic Variable. In P. Coulmas (Ed.), The Handbook of Sociolinguistics (pp. 142-176). Oxford: Blackwell.

El-Yasin, M. K. (1985). Basic word order in classical Arabic and Jordanian Arabic. Lingua, 65(1-2), 107-122. https://doi.org/10.1016/0024-3841(85)90022-1

Holmes, J. (1995). Women, Men and Politeness. London: Longman.

Jarrah, M. (2016). Weightlessness Preservation in Jordanian Arabic Varieties: A Stratal OT Analysis.

Jarrah, M. A. (2016). Explicit-implicit distinction: A review of related literature. Advances in Language and Literary Studies, 7(1), 175-184.

Jarrah, M. A., Alhaisoni, E., Hammouri, Y. M., \& Shehadeh, M. S. (2013). A Semantico-Phonological 
Investigation of Proper Nouns. International Journal of Linguistics, 5(3), 1-20. https://doi.org/10.5296/ijl.v5i3.3152

Jarrah, M., \& Zibin, A. (2016). On Definiteness and Information Trigger in Arabic. Advances in Language and Literary Studies, 7(2), 55-67.

Jarrah, M., \& Zibin, A. (2016). Syntactic investigation of nunation in Haili Arabic. SKY Journal of Linguistics, 29, 39-62.

Kangasharju, H. (2002). Alignment in Disagreement: Forming Oppositional Alliances in Committee Meetings. Journal of Pragmatics, 34, 1447-1471. https://doi.org/10.1016/S0378-2166(02)00073-5

Lackoff, T. (2001). Nine Ways of Looking at Apologies: The necessity for Interdisciplinary Theory and Method in Discourse Analysis. In D. Schifferin, D. Tannen, \& H. Hamilton (Eds.), (2003). The Handbook of Discourse Analysis (pp. 197-245). U.S.A.: Blackwell Publication.

Leech. G. (1983). Principles of Pragmatics. London: Longman.

Levinson, S. (1983). Pragmatics. Britain: Cambridge University Press.

Milroy, L. (1980). Language and Social Network. United States: University Park Press.

Olashtain, E. (1989). Apologies across Language. In S. Blum-Kullka, J. House, \& G. Kasper (Eds.), Cross Cultural Pragmatics: Request and Apologies (pp. 155-173). Norwood: Albex Pulblishing Corporation.

Rakhieh, B. A. (2009). The phonology of Ma'ani Arabic: Stratal or parallel OT. University of Essex.

Searle, J. (1979). Expression and Meaning: Studies in the Theory of Speech Acts. Cambridge: Cambridge University Press. https://doi.org/10.1017/CBO9780511609213

Stenstorm, A. (1994). An Introduction to Spoken Interaction. London: Longman.

Stockwell, P. (2007). Sociolinguistics. New York: Routledge.

Taha, K., Jarrah, M. A., \& Al-Jarrah, R. S. (2014). The discoursal Arabic coordinating conjunction wa (and). International Journal of Linguistics, 6(4), 172. https://doi.org/10.5296/ijl.v6i4.4547

Wardhaugh, R. (1986). An Introduction to Sociolinguistics. UK: Blackwell.

Webster's Ninth New Collegiate Dictionary. (1990). (7th ed.). Springfield: Merriam Company.

Wierzbicka, A. (1987). English Speech Acts Verbs: A Semantic Dictionary. New York: Academic Press.

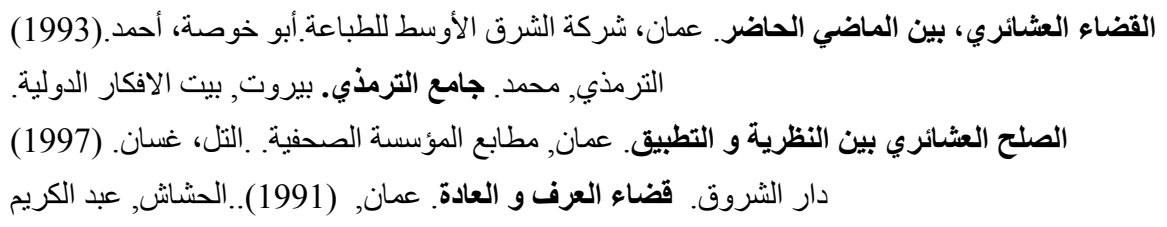

\section{Notes}

Note 1. See Al-Yasin (1985), Rakhiah (2009) and Jarrah (2016) for works on the dialect spoken in Jordan.

Note 2. It is observed that past verbs occur much in this type of agreement. I interpret this following the lines of Alhaisoni et al. (2012) that the past form of the verb is used to show high levels of evidentiality and thus respect.

Note 3. In North Jordan jurisdictions, the provisional agreement has to be sought during three days and one third of committing the offensive behavior like car accidents. Otherwise, the perpetrator is considered guilty.

Note 4. The use of honorifics implies that any request by the inflected party will be answered (see, Taha et al., 2013; Al-Jarrah et al., 2015; Jarrah, 2016), among many others, for further discussion on how words are used to implicate a hidden message, and Altakhaineh et al. (2014) for a different approach)

Note 5. Offering is introduced by the use of the definite article in almost all nouns; this is to imply that, for instance, the offering is genuine and unique (see, Al-Jarrah et al., 2013; Jarrah \& Zibin, 2016, for further discussion of the use of the definite article). 


\section{Copyrights}

Copyright for this article is retained by the author(s), with first publication rights granted to the journal.

This is an open-access article distributed under the terms and conditions of the Creative Commons Attribution license (http://creativecommons.org/licenses/by/4.0/). 